\title{
Histological Characterization of Resistance to Different Root-Knot Nematode Species Related to Phenolics Accumulation in Capsicum annuum
}

\author{
A. Pegard, G. Brizzard, A. Fazari, O. Soucaze, P. Abad, and C. Djian-Caporalino
}

Institut National de la Recherche Agronomique (INRA), Unit Plant-Microbe Interactions and Plant Health (IPMSV), 400 route des Chappes,

Les Templiers, 06903 Sophia Antipolis, France.

Accepted for publication 14 October 2004.

\begin{abstract}
Pegard, A., Brizzard, G., Fazari, A., Soucaze, O., Abad, P., and DjianCaporalino, C. 2005. Histological characterization of resistance to different root-knot nematode species related to phenolics accumulation in Capsicum annuиm. Phytopathology 95:158-165.

In the pepper Capsicum annuum CM334, which is used by breeders as a source of resistance to Phytophthora spp. and potyviruses, a resistance gene entirely suppresses reproduction of the root-knot nematode (Meloidogyne spp.). The current study compared the histological responses of this resistant line and a susceptible cultivar to infection with the three most damaging root-knot nematodes: $M$. arenaria, $M$. incognita, or $M$. javanica. Resistance of CM334 to root-knot nematodes was associated with unidentified factors that limited nematode penetration and with post-

penetration biochemical responses, including the hypersensitive response, which apparently blocked nematode migration and thereby prevented juvenile development and reproduction. High-performance liquid chromatography analysis suggested that phenolic compounds, especially chlorogenic acid, may be involved in CM334 resistance. The response to infection in the resistant line varied with root-knot nematode species and was correlated with nematode behavior and pathogenicity in the susceptible cultivar: nematode species that quickly reached the vascular cylinder and initiated feeding sites in the susceptible cultivar were quickly recognized in CM334 and stopped in the epidermis or cortex. After comparing our data with those from other resistant pepper lines, we suggest that timing of the resistance response and the mechanism of resistance vary with plant genotype, resistance gene, and root-knot nematode species.
\end{abstract}

The root-knot nematode (Meloidogyne spp.) is an important pathogen of several Solanaceous crops, especially pepper, potato, and tomato $(42,55)$. Roots attacked by this parasite exhibit characteristic root galls, and infected plants grow poorly or even die because of vascular dysfunction. As sedentary endoparasites, Meloidogyne spp. have complex trophic relationships with their host plant and induce specialized feeding structures known as giant cells, which are essential to the nutrition and development of the nematode (7).

Economics, availability, and government regulations have drastically restricted the use of nematicides for controlling plantparasitic nematodes. Alternatives to nematicides are needed and, among the alternatives, host plant resistance is especially valuable because resistance can provide effective, economical, and environmentally safe nematode control. Unfortunately, large-scale and long-term cultivation of cultivars with single resistance genes may enable root-knot nematodes to overcome that resistance $(16,23$, $38,46,58)$. Resistance efficacy and durability, however, may be increased by combining several genes with different resistance mechanisms, as has been demonstrated for resistance to scald in barley (9), rice bacterial blight (58), lentil Ascochyta blight (63), and $P v r 4$ virus in pepper (11).

Resistance to root-knot nematodes was associated with several dominant genes in the pepper Capsicum annuum $(19,33)$. This species of Solanaceae is one of the most cultivated vegetable species after tomato in the United States and in developing countries (28). Hendy et al. (33) have shown that two Capsicum lines (PM217 and PM687) were resistant to root-knot nematodes and

Corresponding author: C. Djian-Caporalino; E-mail address: caporali@ antibes.inra.fr

DOI: 10.1094/PHYTO-95-0158

(c) 2005 The American Phytopathological Society identified at least four dominant genes. We confirmed their observations and found other dominant genes conferring resistance (19). Some were highly specific, whereas others $\left(M e_{1}\right.$ in PM217 and $\mathrm{Me}_{3}$ in PM687) were effective against a wide range of species. One gene, $\mathrm{Me}_{3}$, has been located on the pepper chromosome 9 (20), and localization of the other resistance genes is in progress. Previous comparative histological studies $(8,32)$ showed that the two broad-spectrum resistance genes $\left(M e_{1}\right.$ and $\left.M e_{3}\right)$ induced different response patterns to nematode infection depending on the pepper lines.

In the family Solanaceae, resistance usually is associated with a hypersensitive reaction (HR), a rapid and localized cell death in the infected plant in response to pathogen attack. Nematode juveniles surrounded by necrotic cells fail to develop, and they die. The response can occur early and thereby prevent parasite penetration or migration (48). It also can occur later, inhibiting the development of giant cells and suppressing parasite development and multiplication (50). Several authors showed that the HR is locally accompanied by the production or release of highly reactive forms of oxygen, salicylic acid (18), phenolic compounds $(4,29,34,39,43,49)$, or other compounds involved in extracellular signal transduction pathways. Defense gene activation, structural changes (especially cell wall reinforcement), and phytoalexin synthesis (35) also often are observed. These phenomena occur at the infection site within minutes after penetration $(29,49)$.

The inbred pepper line Criollo de Morelos 334 (CM334) displayed a high level of resistance to the three main species of rootknot nematodes: $M$. arenaria, $M$. incognita, and $M$. javanica (19). We named the gene conferring this resistance $M e_{7}$ (C. DjianCaporalino, unpublished data). CM334, which originated from the wild population Criollo de Morelos (Mexico) and which produces small and pungent fruit, also has been used in breeding programs as a source of resistance to Phytophthora capsici (47) and potyviruses (21). 
The general objectives of the present work were to understand resistance mechanisms to root-knot nematodes in pepper and to find multiple sources or mechanisms so as to enhance resistance durability. Given these general objectives, one specific objective of this article was to quantify nematode penetration by $M$. arenaria, $M$. incognita, and $M$. javanica into the resistant line (CM334) and a susceptible cultivar. A closely related second objective was to compare histological and histochemical responses of the resistant CM334 and a susceptible cultivar to these nematodes. A third objective was to compare and contrast resistance in CM334 with that in two other previously studied sources of nematode resistance in pepper (PM687 and PM217).

\section{MATERIALS AND METHODS}

Nematodes. Experiments were conducted with three Meloidogyne spp. from the INRA Antibes collection: $M$. arenaria (from Monteux, France), M. incognita (from Calissane, France), and M. javanica (from Avignon, France). These species were identified using sequence characterized amplified region (SCAR) based polymerase chain reaction (PCR assays) (65). For each species, hatched second-stage juveniles (J2) were collected from infected roots of susceptible tomato plants (cv. Saint Pierre) held in a mist chamber. $\mathrm{J} 2$ were stored at $4^{\circ} \mathrm{C}$ for less than $24 \mathrm{~h}$ before use.

Plant material. The pepper cv. Doux Long des Landes (DLL, from a French local population) was used as a susceptible control. It developed galls and allowed nematode reproduction (19). The resistant pepper line CM334 was supplied by A. Palloix (INRA Montfavet, France). It was selfed in insect-proof cages to eliminate outcrossing and was assumed to be homozygous. Experiments were conducted in a growth chamber with a mean temperature of $23^{\circ} \mathrm{C}$, a regime of $11 \mathrm{~h}$ of light and $13 \mathrm{~h}$ of dark, and 60 to $70 \%$ relative humidity. Plants were grown individually in small plastic pots containing $75 \mathrm{~cm}^{3}$ of sterilized sand and were randomized within the growth chamber.

Penetration experiment. For each Meloidogyne spp., 50 plants of DLL and CM334 were inoculated with a water suspension containing $600 \mathrm{~J} 2$. At 1, 2, 3, 4, and 5 days after soil infestation, seedlings were removed from pots and root systems were washed carefully, fixed, and stained with acid fuschin (10). The root system of each plant was examined under a stereo microscope. Penetration was evaluated by counting the stained $\mathrm{J} 2$ in the roots. For each combination of pepper genotype and Meloidogyne spp., five plants were analyzed on each sampling day. Five additional plants of DLL and CM334 also were inoculated with the same batches of J2, and egg-masses were colored with eosine (19) and counted 6 weeks later. The experiment was repeated.

A two-way analysis of variance (ANOVA) was performed on the data, followed by mean separation with Fisher's protected least significant difference (PLSD, $P=0.05$ ) to compare rates of penetration and reproduction. All the statistical work was done using Analyse-it software for Microsoft Exel. Because no significant differences existed between the repeated experiments, data were pooled for analysis.

Plant inoculation and tissue processing for histopathological studies. Four-week-old plants with six to eight expanded leaves were inoculated with $10,000 \mathrm{~J} 2$ in $3 \mathrm{ml}$ of aqueous suspension. Nematodes were added at six points around each stem and as close as possible to the root system. Roots were removed from the pots and carefully washed $1,2,3,5,7,9$, or 14 days after inoculation (DAI). Four plants were used for each combination of pepper line, Meloidogyne sp., and time, and the experiment was repeated.

For each plant, five root segments $(0.5$ to $1.0 \mathrm{~cm}$ long) were selected and excised. Root segments were immersed immediately in $1 \%$ (vol/vol) glutaraldehyde and $4 \%$ (vol/vol) formaldehyde in $100 \mathrm{mM}$ sodium phosphate buffer, $\mathrm{pH} 7.2$, at room temperature and were maintained on a rotary shaker for $3 \mathrm{~h}$. They were rinsed

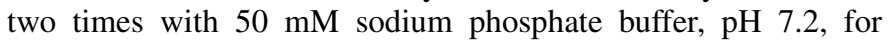

30 min before dehydration and then dehydrated with agitation in a graded ethanol series (10 to $100 \%, 10 \mathrm{~min}$ at each concentration), followed by two additional steps in $100 \%$ ethanol. They were then imbedded in Technovit 7100 (an epoxy resin provided by Kulzer Friedrichsdorf, Germany) according to manufacturer's protocol. Longitudinal sections $(3 \mu \mathrm{m})$ were mounted on poly-L-lysin loaded slides. One of two glass sides was stained for 4 to $5 \mathrm{~min}$ with $0.5 \%$ toluidine blue in $0.1 \mathrm{M}$ sodium phosphate buffer, $\mathrm{pH}$ 5.5 , rinsed with ultra-pure water, and dried. Stained reactions were examined under a Zeiss Axioplan 2 light microscope. Unstained sections of roots were examined and photographed using the light microscope with a UV filter set A2 Zeiss 02 (4880020000) with 365-nm excitation and 420-nm emission to reveal aromatic compounds. When observed under UV light, yellow and orange autofluorescence revealed the presence of phenolic compounds and a pale blue-autofluorescence revealed the presence of lignified cells $(1,52)$. For each combination (pepper line, Meloidogyne sp., and time after inoculation), 10 sections from each of the five different root segments were examined. An average of 400 toluidine blue-stained root sections was observed for each combination of time, Meloidogyne sp., and cultivar. For the resistant cv. CM334, $\approx 400$ unstained root sections also were observed under UV light.

Identification and chromatographic analysis of phenolic compounds. Because phenolic compounds have been associated with resistance $(4,29,34,39,43,49)$, we quantified the phenolic content of resistant and susceptible pepper roots infected with the three Meloidogyne spp. Four-week-old plants of each line were inoculated with 10,000 J2 for each Meloidogyne sp. as described for the histological studies. Plants growing in nematode-free sand were used as a control. At 5 DAI, roots were removed from pots and washed carefully in water. Two plants for each combination of pepper line, Meloidogyne sp., and the control were analyzed. Inoculated and control fresh root segments $(0.4 \mathrm{~g})$ were randomly selected, excised, and placed separately into $10 \mathrm{ml}$ of $100 \%$ methanol for $24 \mathrm{~h}$. After roots were removed, $1 \mathrm{ml}$ of each extract was dried under vacuum in a rotary evaporator at room temperature and resuspended in $100 \mu \mathrm{l}$ of methanol. The concentrated extracts were filtered $(0.2 \mu \mathrm{m})$ and stored at $4^{\circ} \mathrm{C}$, and $20 \mu \mathrm{l}$ of each was separated and analyzed by high-performance liquid chromatography (HPLC). HPLC separations were performed using an Alltima C18 column and a UV detector coupled to a personal computer and controlled by in-house software. The separation was monitored from 200 to $350 \mathrm{~nm}$. All solvents were of chromatographic grade (Sigma-Aldrich, France). Before use, the HPLC capillary was rinsed with water and methanol. A gradient of methanol prepared in aqueous $0.5 \% \mathrm{H}_{3} \mathrm{PO}_{4}$ made it possible to reliably separate several phenolic compounds. By comparison with standard curves prepared with known phenolic compounds, major peaks were identified and quantified. The experiment was repeated.

\section{RESULTS}

Penetration by Meloidogyne spp. into roots of susceptible DLL and resistant CM334 cultivars. The nematodes penetrated roots of both pepper lines, but the two-way ANOVA revealed a significant influence of plant genotype $(P<0.0001)$, Meloidogyne sp. $(P<0.0001$ to $P=0.02)$, and time after inoculation $(P<$ $0.0001)$. By 3 DAI, significantly more $(P<0.0001) \mathrm{J} 2$ had penetrated the susceptible cultivar than the resistant line (Table 1). This difference increased substantially with time. At 5 DAI, the maximum number of $\mathbf{J} 2$ had penetrated. Whereas 29 to $43 \%$ of the inoculum penetrated the roots of the susceptible pepper, $<4 \%$ penetrated the roots of CM334. Significant differences $(P=$ 0.0001 to $P=0.0031)$ in the ability to invade the roots also occurred among Meloidogyne spp. by 2 or 3 DAI. More J2 of M. incognita than of $M$. javanica or $M$. arenaria penetrated the roots of 
DLL and CM334. In DLL, egg masses were produced by 27, 23, and $18 \%$ of $\mathrm{J} 2$ inoculum for $M$. incognita, $M$. javanica, and $M$. arenaria, respectively. In CM334, however, no egg masses were detected after 6 weeks.

Histological observations of susceptible DLL roots. Examination of approximately 8,400 susceptible root sections showed that, although all three nematode species were able to penetrate roots, migrate, and develop normally (Fig. 1), they differed in time required to reach the vascular cylinder and to develop giant cells. Observation of numerous sections indicated that the differences were constant under the experimental conditions. Most of the $\mathrm{J} 2$ entered the roots and moved intercellularly through the root tip and elongation zone (Fig. 1A and E). Several J2 invaded the same site (especially $M$. incognita) and migrated in groups through the cortex (Fig. 1I). The first cellular changes appeared 3 DAI for $M$. arenaria and $M$. javanica (Fig. 1B), and 5 DAI for $M$. incognita (Fig. 1J). At 5 DAI, giant cells contained two nuclei for $M$. incognita (Fig. 1J) and four or more nuclei for M. arenaria or $M$. javanica (Fig. 1C and F). Giant cells containing multiple nuclei and juveniles molted to stage 3 were seen 7 DAI for $M$. arenaria and $M$. javanica (Fig. $1 \mathrm{G}$ ), and 9 DAI for $M$. incognita (Fig. 1K). Giant cells reaching the maximum length of $400 \mu \mathrm{m}$ were seen 9 DAI for $M$. arenaria and $M$. javanica (Fig. $1 \mathrm{D}$ and $\mathrm{H}$ ) and $14 \mathrm{DAI}$ for $M$. incognita (Fig. 1L). Six weeks after inoculation, galls were $2 \mathrm{~mm}$ in diameter for all three species in the susceptible line.

Histological observations of resistant CM334 roots. Examination of approximately 16,800 resistant root sections showed that, among the few $\mathrm{J} 2$ penetrating the roots for the three species, all remained clustered at the root apex and died without development (i.e., no J2 was found in the vascular stele; J2 were found in the epidermis or cortex only) and there was no formation of giant cells. Moreover, the $\mathrm{J} 2$ were surrounded by necrotic cells. The lesions, which were green when stained with toluidine blue, were first discrete and highly localized around the nematode head (Fig. 2A, E, and I). During migration, nematodes left a patch of necrotic cells which usually was parallel to the root axis (Fig. $2 \mathrm{~F}$ and L) and which stained more intensely with time.

When resistant root sections were examined under UV light, a yellow or orange autofluorescence characteristic of aromatic compounds was seen within the cells and in the cell walls. This fluorescence appeared early, became intensely bright orange 3 DAI, and only occurred in epidermic and cortical cells around the nematodes. This reaction was observed as early as 1 DAI in response to $M$. arenaria, 1 or 2 DAI in response to $M$. javanica, or 3 DAI in response to $M$. incognita (Fig. 2A, E, and J). Similar fluorescence was not observed in the susceptible roots and also was absent before infection in the resistant roots (data not shown).

At 1 or 2 DAI with $M$. arenaria or $M$. javanica, and 5 DAI with $M$. incognita, yellow or orange autofluorescence was detected in intercellular spaces around the nematode (Fig. 2A, E, and K). For $M$. incognita, it was intracellular 3 DAI, but not in the intercellu- lar space (Fig. 2J). Substantial necrosis also occurred at the root apex when multiple $\mathrm{J} 2$ had penetrated (Fig. $2 \mathrm{~J}$ and $\mathrm{K}$ ).

In CM334 cellular necrosis differed for the three Meloidogyne spp. For $M$. arenaria, necrosis was concentrated in the epidermis (the head of the $\mathrm{J} 2$ was surrounded by necrotic cells) (Fig. 2A) and outer cortex (Fig. 2B and 2C). In contrast, necrosis occurred in the outer and intermediate cortex for M. javanica (Fig. 2E, F, $\mathrm{G}$, and $\mathrm{H}$ ) and in the whole cortex for M. incognita (Fig. 2I, J, K, and L). Necrosis occurred shortly after penetration for $M$. arenaria (Fig. 2A) and M. javanica, but later for M. incognita (Fig. 2J).

Signs of nematode death were first visible 7 DAI for $M$. arenaria or M. javanica and 9 DAI for M. incognita (Fig. 2D, G, and H). Because necrotic cells of both nematode and adjacent root exhibited a darkening of the orange fluorescence, visualizing the nematode was difficult (Fig. 2L). Fluorescence increased on thickened cell walls and in intercellular spaces near the nematode.

No necrosis occurred on roots of the susceptible cultivar. Although no yellow or orange autofluorescence was detected in susceptible roots, vessel cell walls of the resistant line and susceptible cultivar exhibited a pale blue-white autofluorescence under UV light. A pale blue-white autofluorescence also was observed in walls of some necrotic cells 7 or 9 DAI of resistant roots (Fig. 2D, H, and L).

HPLC analysis of phenolic compounds. Phenolic compounds were extracted from noninoculated and inoculated susceptible and resistant roots and analyzed by HPLC. Results were similar for all three nematode species and, to simplify the presentation, only data for M. arenaria at $254 \mathrm{~nm}$ are shown (Fig. 3).

Based on comparison with a standard curve prepared with known phenolic compounds, a major peak was identified as chlorogenic acid (retention time: $26.6 \mathrm{~min}$ ) in extracts of inoculated roots of the resistant CM334 line. Amounts of chlorogenic acid differed between extracts of noninoculated and inoculated roots (sampled 5 DAI) within each pepper cultivar (Table 2). Inoculated CM334 roots contained 59 times more chlorogenic acid per gram of root tissue than noninoculated CM334, and 7 times more than inoculated DLL.

An additional specific peak only present in inoculated CM334 roots (retention time: $34 \mathrm{~min}$ ) was unidentified. This phenolic compound was eight times less concentrated than the chlorogenic acid.

\section{DISCUSSION}

The first aims of this study were to compare root-knot nematode penetration and subsequent development in a resistant pepper line and a susceptible pepper cultivar. We showed that the three different Meloidogyne spp. were able to penetrate the roots of both pepper genotypes but that penetration differed among the nematode species and was much reduced in the resistant line. Nematode development after penetration also was greatly affected

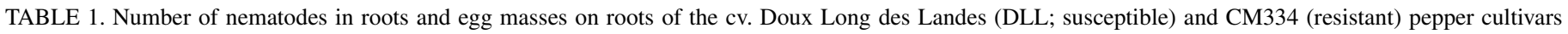
inoculated with 600 Meloidogyne second-stage juveniles $(\mathrm{J} 2)^{\mathrm{Z}}$

\begin{tabular}{|c|c|c|c|c|c|c|}
\hline \multirow[b]{2}{*}{ Time after inoculation } & \multicolumn{3}{|c|}{ Susceptible DLL } & \multicolumn{3}{|c|}{ Resistant CM334 } \\
\hline & M. incognita & M. javanica & M. arenaria & M. incognita & M. javanica & M. arenaria \\
\hline \multicolumn{7}{|c|}{ No. of $\mathrm{J} 2$ per root system } \\
\hline 1 day & $36 \pm 6 a$ & $15 \pm 4 \mathrm{bc}$ & $21 \pm 3 a b$ & $8 \pm 2 c$ & $6 \pm 1 \mathrm{c}$ & $6 \pm 1 \mathrm{c}$ \\
\hline 2 days & $46 \pm 7 \mathrm{a}$ & $24 \pm 3 b$ & $20 \pm 3 b$ & $19 \pm 4 b c$ & $7 \pm 1 c$ & $7 \pm 1 \mathrm{c}$ \\
\hline 3 days & $82 \pm 6 a$ & $56 \pm 3 b$ & $55 \pm 3 b$ & $22 \pm 4 c$ & $9 \pm 2 d$ & $9 \pm 1 d$ \\
\hline 4 days & $229 \pm 14 \mathrm{a}$ & $163 \pm 9 b$ & $170 \pm 8 b$ & $19 \pm 3 c$ & $4 \pm 1 d$ & $3 \pm 1 d$ \\
\hline 5 days & $255 \pm 11 \mathrm{a}$ & $184 \pm 11 b$ & $173 \pm 15 b$ & $18 \pm 2 c$ & $7 \pm 2 \mathrm{~cd}$ & $6 \pm 1 d$ \\
\hline \multicolumn{7}{|c|}{ No. of egg-masses per root system } \\
\hline 6 weeks & $160 \pm 14 \mathrm{a}$ & $136 \pm 10 \mathrm{ab}$ & $107 \pm 11 b$ & $0 \mathrm{c}$ & $0 \mathrm{c}$ & $0 \mathrm{c}$ \\
\hline
\end{tabular}

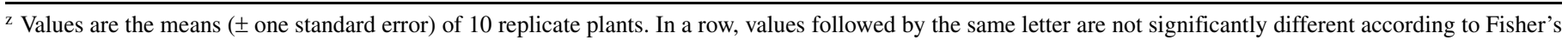
protected least significant difference at $P=0.05$. DAI $=$ days after inoculation. 
by host genotype and nematode species. Our data suggest that CM334 pepper has at least two kinds of resistance to Meloidogyne spp. One kind of resistance suppresses penetration by $\mathrm{J} 2$ and the other kind blocks development after penetration.

Plant resistance can occur at several levels. Failure of J2 to penetrate roots of resistant CM334 (2\% of penetration in resistant roots compared with $30 \%$ in susceptible roots) may indicate physical root barriers. Such barriers were suggested previously for resistant grape rootstocks (2,27), a cotton cultivar (3), and a soybean cultivar (22). It also may indicate that the roots did not attract or even repelled $\mathrm{J} 2$, or that $\mathrm{J} 2$ penetrated and then left the roots. Such protection was shown for Cucumis sativus: a triterpene, cucurbitacin, that repelled Meloidogyne J2 was isolated from root exudates (31). Similarly, amino acids exuded from Sesamum indicum roots have a nematostatic effect on Meloidogyne $\mathrm{J} 2$ (59).

Moreover, in the resistant line, J2 remained vermiform and clustered in cortical cells at the root apex. No galling occurred and no egg mass developed. This suggests that CM334 has very active post-penetration biochemical defense mechanisms which blocked nematode migration, development, and reproduction. The post-penetration response of the incompatible CM334 roots was

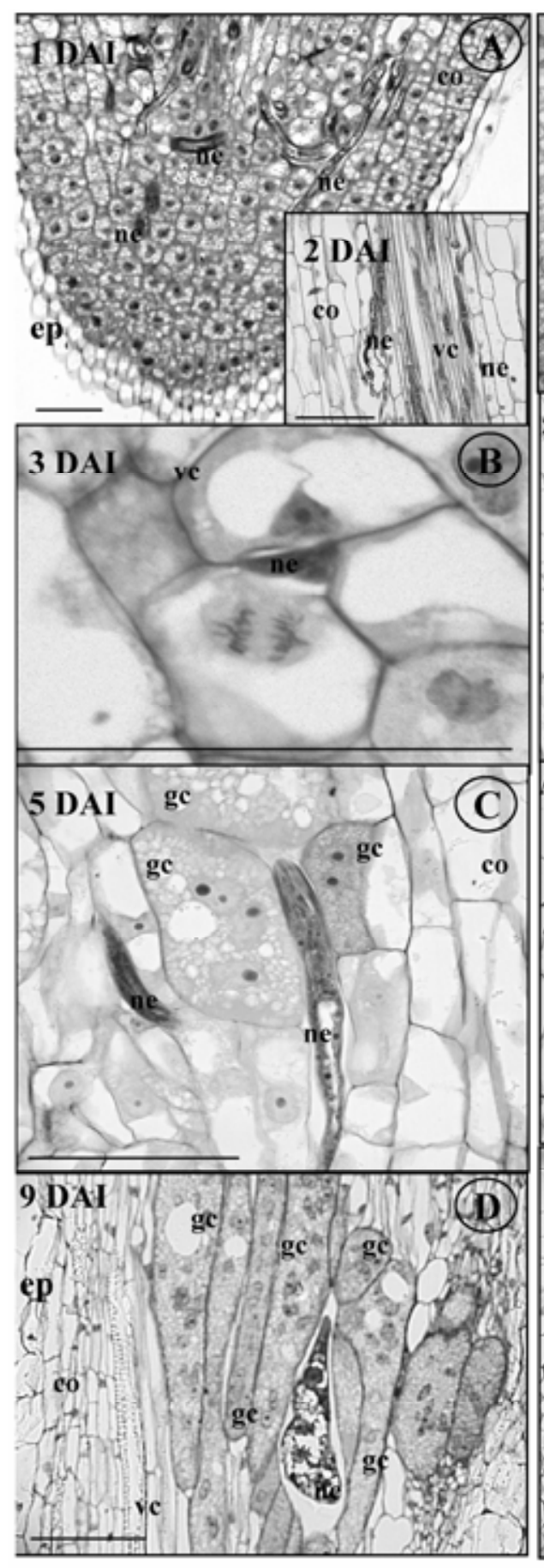

Ma susceptible

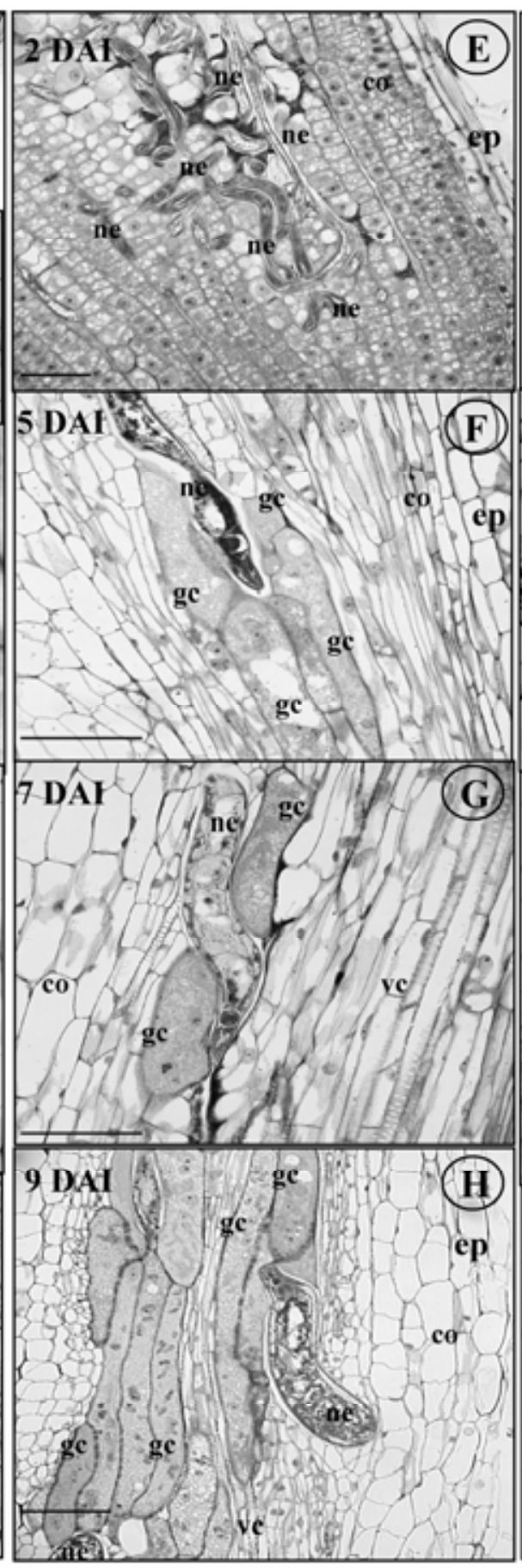

Mj susceptible

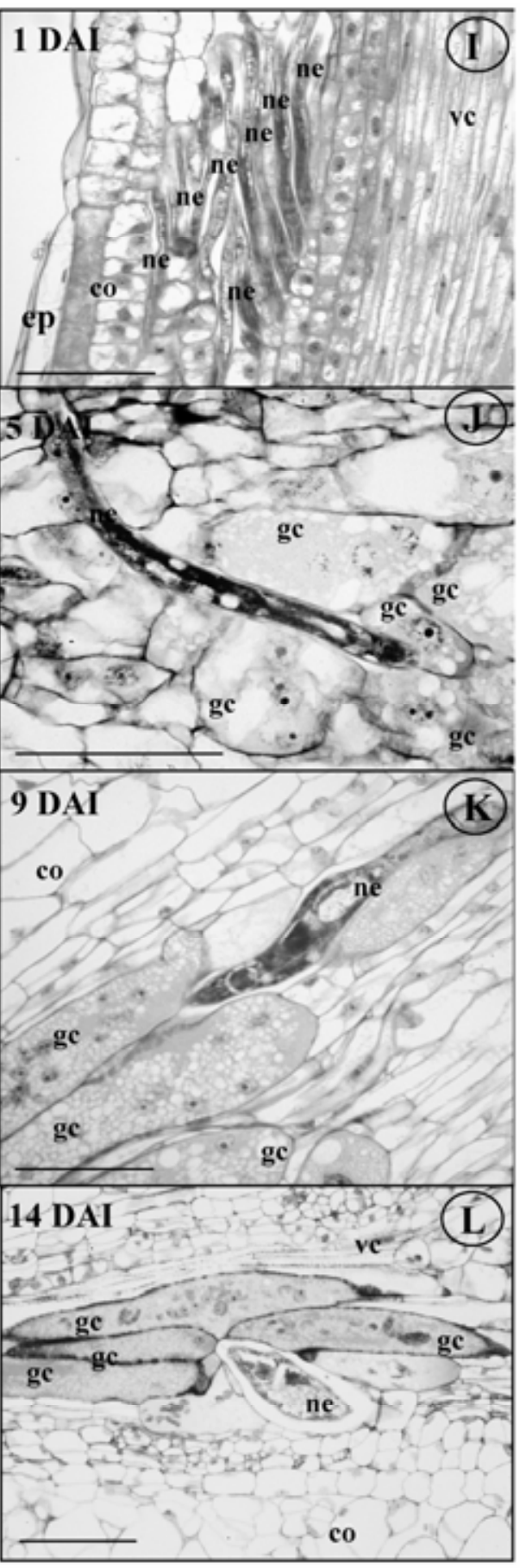

Mi susceptible

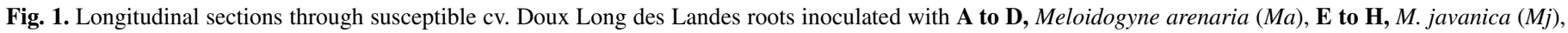

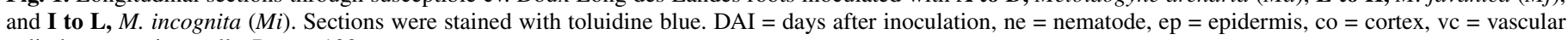
cylinder, $\mathrm{gc}=$ giant cells. Bars $=100 \mu \mathrm{m}$. 
considered a classical HR. This HR occurred more quickly than did the susceptible response.

As reported by others for different plants $(30,39,40,48,57,61)$, the HR in CM334 involved substantial necrosis and it seems possible, although not yet proven, that the necrosis limits nematode development.

Among molecules that may actively contribute to plant defense against nematodes and other pathogens, phenolics are often cited

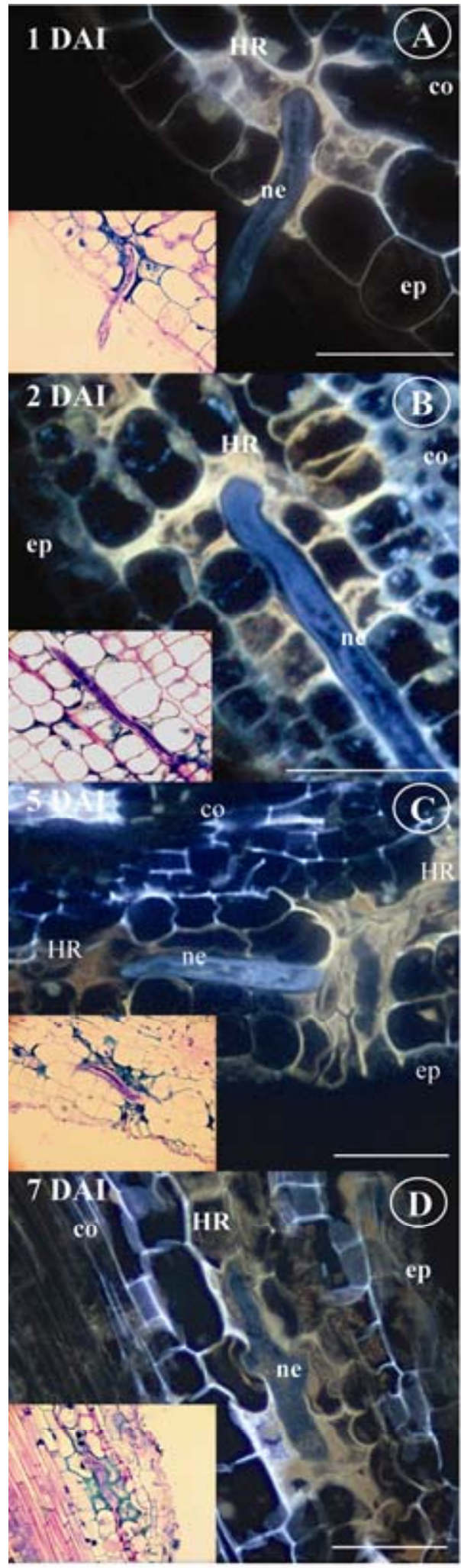

Ma resistant
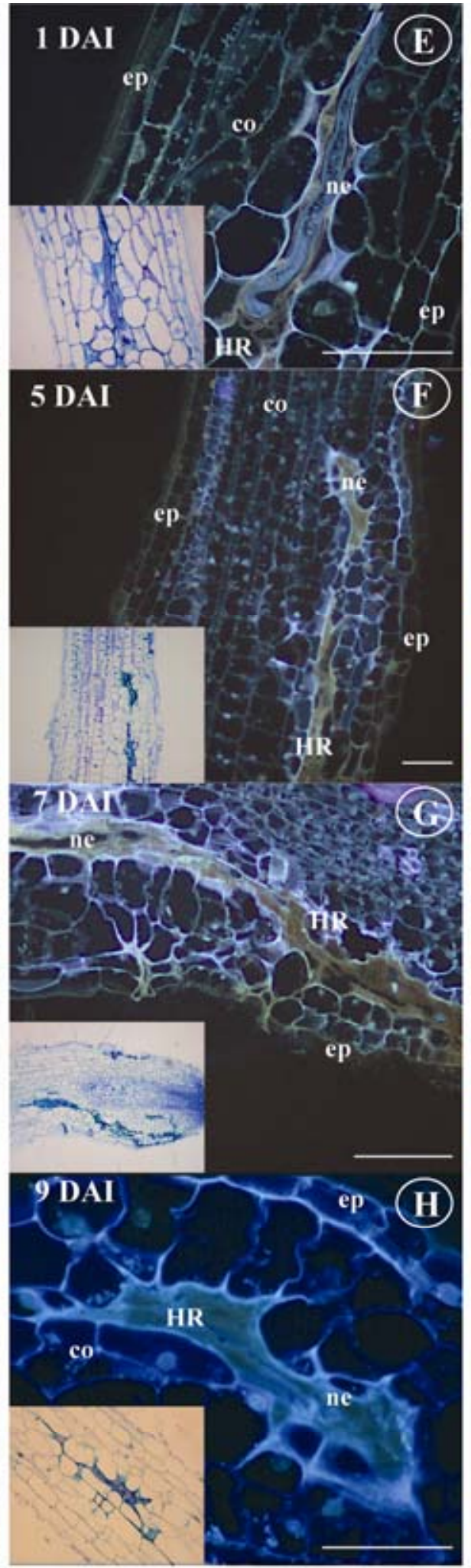

Mj resistant
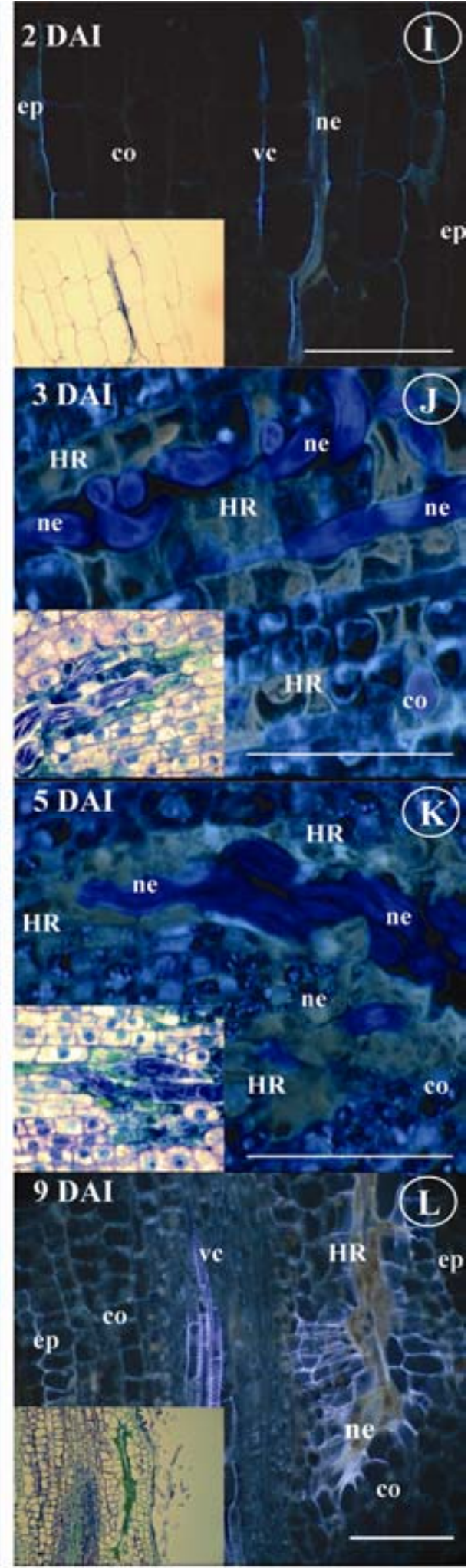

\section{Mi resistant}

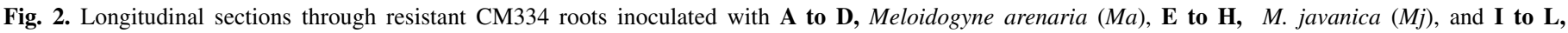

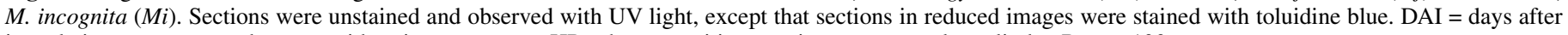
inoculation, $\mathrm{ne}=$ nematode, $\mathrm{ep}=$ epidermis, $\mathrm{co}=$ cortex, $\mathrm{HR}=$ hypersensitive reaction, $\mathrm{vc}=$ vascular cylinder. Bars $=100 \mu \mathrm{m}$. 
$(4,6,29,34,39,43,44,49)$. In the current study, histological analysis, UV light observations, and HPLC analysis of noninfected and infected pepper roots showed an association between phenolics and resistance to root-knot nematodes. In fact, these compounds accumulated locally inside cells close to the migrating nematode early in injured tissues of the resistant line only. Phenolic compounds were concentrated in a small number of cells and in the intercellular spaces of root tissue around J2 when observed under UV light. We identified chlorogenic acid as the major phenolic compound in CM334 pepper roots penetrated by nematodes. Chlorogenic acid is known to affect nematode coordination (34). The presence of this compound may cause the browning and the resistant reaction of both Nicotiana repanda (43) and Nemared tomato $(34,49)$ to $M$. incognita. In vivo activity of chlorogenic acid could be due to the quinic acid or caffeic acid components which are released by the action of hydrolytic enzymes such as esterases (14). The oxidized forms of phenolic compounds, which also occurred in high concentrations in roots of resistant tomato plants, might contribute to the $M$. incognita resistance (4) by creating a toxic environment for nematode penetration and multiplication. This also was proposed for fungi (5) and bacteria (45). Because they can be detected with UV light, histochemical procedures, or HPLC, phenolics may be useful for identifying additional resistant cultivars.

In related work, we identified several genes responsible for resistance to Meloidogyne spp. in different Capsicum annuum lines (PM217, PM687, and CM334) and in cv. Yolo Wonder (YW) $(19,33)$. The timing, location, and nature of the resistant reaction appear to vary depending on the plant genotype, the particular resistance gene, and the Meloidogyne sp. (Table 3). There was immediate cellular necrosis in the root epidermis adjacent to the J2 $(8,32)$ (sometimes only the head had penetrated the root epidermis) in response to $M$. incognita in PM687 ( $\mathrm{Me}_{3}$ gene) $(8,32)$,
M. arenaria in PM217 ( $M e_{1}$ gene) (32), and in CM334 ( $M e_{7}$ gene), as reported with the $M i_{-1.2}$ gene in resistant tomato plants (48). Necrosis was observed in the intermediate cortex 1 or 2 DAI in PM217 ( $M e_{1}$ gene) (32), PM687 ( $\mathrm{Me}_{3}$ gene) (32), and CM334 $\left(\mathrm{Me}_{7}\right.$ gene) with $\mathrm{M}$. javanica. Cellular necrosis was visible only 3 DAI for $M$. incognita and was concentrated in the inner cortex near the vascular cylinder in CM334 (Me 7 gene). Small giant cells with few gathered nuclei began to develop within 4 DAI in resistant pepper PM217 $\left(\mathrm{Me}_{1}\right.$ gene) with $M$. incognita, PM687 $\left(\mathrm{Me}_{3}\right.$ gene) with $M$. arenaria, and YW ( $M e_{5}$ gene) with $M$. javanica $(8,32)$ but necrosis was not evident until 5 DAI and females were unable to reproduce $(15,24,26,51)$. A similar degradation of the feeding site was described for resistant lines of other plants, such as sugar beet, oilseed radish, potato, and soybean $(8,25,53,62,64)$.

Biotypes of Meloidogyne spp. that are able to overcome resistance have been identified $(36,60)$. In artificial selection experiments, an $M$. incognita lineage virulent on pepper plants carrying the $\mathrm{Me}_{3}$ gene was obtained; however, in spite of the drastic selection pressure, the nematode appeared unable to overcome the $M e_{1}$ gene (13). Researchers have proposed that virulence could result from the nematode's ability to overcome the early HR occurring in the outer tissues of the root (i.e., the epidermis and root cortex)

TABLE 2. Quantities of chlorogenic acid in susceptible or resistant pepper roots infected or not infected with Meloidogyne arenaria ${ }^{2}$

\begin{tabular}{lcc}
\hline & \multicolumn{2}{c}{ Chlorogenic acid $(\mu \mathrm{g})$ per gram of root tissue } \\
\cline { 2 - 3 } Roots & Susceptible DLL & Resistant CM334 \\
\hline Noninfected & $67.4 \pm 8.4$ & $9.6 \pm 0.3$ \\
Infected & $77.9 \pm 3.1$ & $569.6 \pm 62.3$ \\
\hline
\end{tabular}

${ }^{\mathrm{z}} \mathrm{DLL}=\mathrm{cv}$. Doux Long des Landes. Values are the means $( \pm$ one standard error) of four replicate root systems.
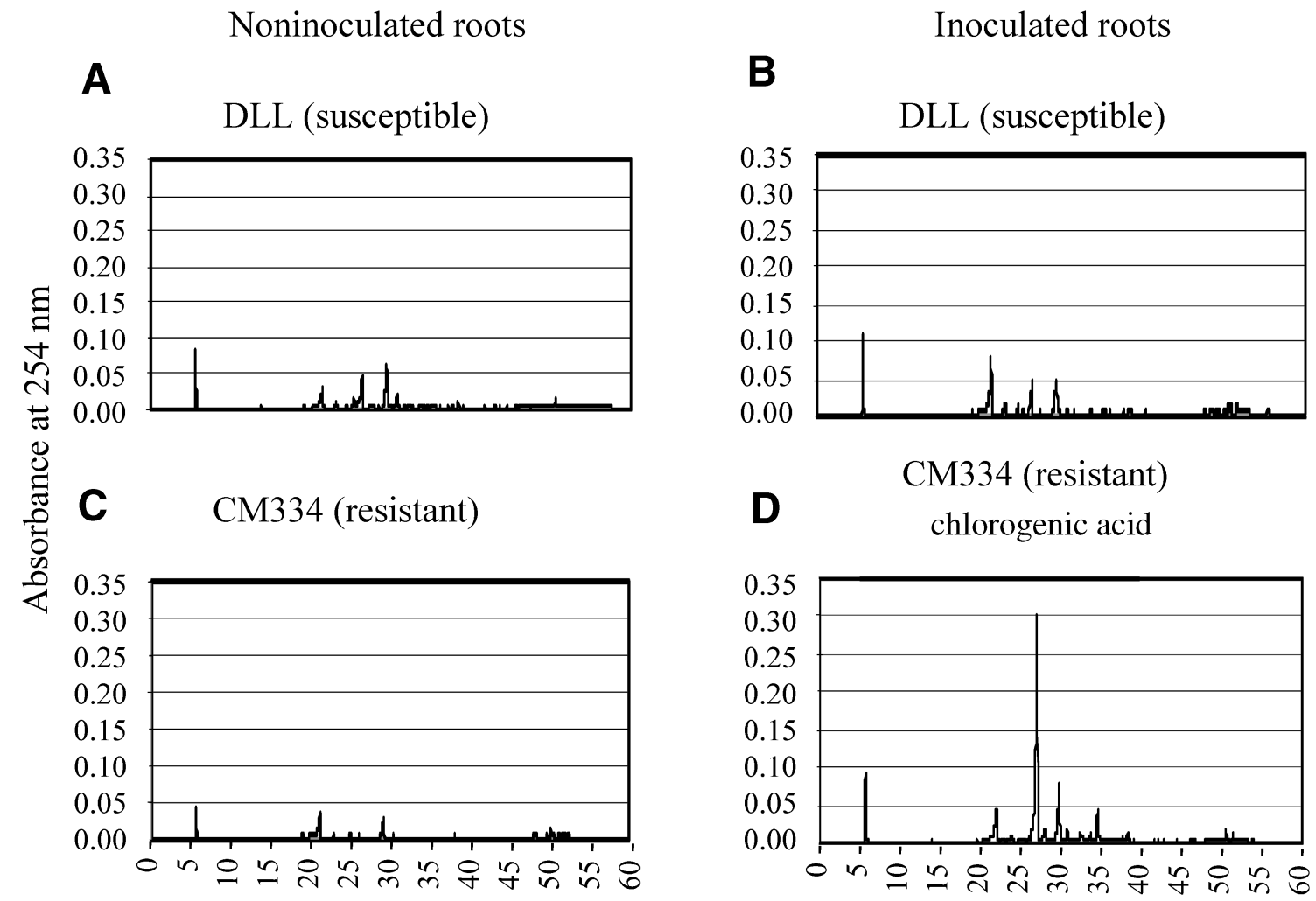

\section{Retention time (minutes)}

Fig. 3. High performance liquid chromatography spectrum at $254 \mathrm{~nm}$ of extracts from cv. Doux Long des Landes (DLL; susceptible) and CM334 (resistant) pepper roots. DLL A, noninoculated and B, inoculated with M. arenaria. CM334 C, noninoculated and $\mathbf{D}$, inoculated with $M$. arenaria. 
TABLE 3. Histopathological reactions to Meloidogyne spp. depending on pepper genotype, resistance gene $(R)$, and nematode species ${ }^{\mathrm{Z}}$

\begin{tabular}{|c|c|c|c|}
\hline Plant genotype $(R)$ & M. arenaria & M. javanica & M. incognita \\
\hline CM334 $\left(\mathrm{Me}_{7}\right)$ & Immediate necrosis in epidermis $1 \mathrm{DAI}$ & Immediate necrosis in cortex 1 or $2 \mathrm{DAI}$ & Necrosis in cortex 3 DAI \\
\hline $\mathrm{PM} 217 *\left(M e_{1}\right)$ & Immediate necrosis in epidermis $1 \mathrm{DAI}$ & Rapid necrosis in cortex 2 DAI & $\begin{array}{l}\text { Small giant cells, necrosis not evident } \\
\text { until } 5 \text { DAI }\end{array}$ \\
\hline $\operatorname{PM687*}\left(\mathrm{Me}_{3}\right)$ & $\begin{array}{l}\text { Rapid necrosis in cortex and small giant } \\
\text { cells with necrosis } 5 \text { DAI }\end{array}$ & Rapid necrosis in cortex 2 DAI & Immediate necrosis in epidermis $1 \mathrm{DAI}$ \\
\hline Yolo Wonder* $\left(\mathrm{Me}_{5}\right)$ & Normal giant cells & $\begin{array}{l}\text { Small giant cells, necrosis not evident until } \\
5 \text { DAI }\end{array}$ & Normal giant cells \\
\hline Susceptible DLL & $\begin{array}{l}\text { Normal giant cells with first cellular } \\
\text { changes } 3 \text { DAI }\end{array}$ & $\begin{array}{l}\text { Normal giant cells with first cellular changes } \\
3 \text { DAI }\end{array}$ & $\begin{array}{l}\text { Normal giant cells with first cellular } \\
\text { changes } 5 \text { DAI }\end{array}$ \\
\hline
\end{tabular}

${ }^{\mathrm{z}}$ DAI = days after inoculation; $*$ indicates results from Hendy et al. (28); DLL = cv. Doux Long des Landes.

$(8,12)$. On the other hand, defense reactions elicited deeper in the root (i.e., close to or within the vascular cylinder) would irreversibly block any further nematode development, thus preventing the selection of a virulent genotype. This hypothesis could be tested by experiments with CM334 and the three Meloidogyne spp. We predict that attempts to select for $M$. arenaria that is virulent on CM334 would succeed (because HR occurs early and in outer tissues), whereas similar attempts with $M$. incognita would fail (because HR occurs late and in inner tissues). The response of the resistant line to the three nematode species seemed to be correlated with the behavior and pathogenicity of the three species on the susceptible cultivar. Those species (M. arenaria and $M$. javanica) that rapidly moved to the vascular cylinder and rapidly initiated giant cells in the susceptible cultivar were quickly recognized and immobilized in the epidermis or cortex of the resistant line. In contrast, $M$. incognita required more time to establish feeding sites in the susceptible cultivar, more $\mathrm{J} 2$ penetrated the roots of DLL and CM334, and apparently this species was not recognized or immobilized by the resistant line until after the $\mathrm{J} 2$ had moved from the cortex and into the vascular cylinder. Perhaps those pathogenicity factors, including proteins secreted by the amphids (56) or stylet $(17,37,54)$, that account for establishment of feeding sites in susceptible plants also trigger defense mechanisms in resistant plants.

Our results suggest diverse mechanisms of resistance in the roots of a nematode-resistant pepper line. We showed that the resistance response varies depending on the host and nematode genotypes, as in fungal systems (41), and that induction of phenolic compounds such as chlorogenic acid may be an important component of resistance in the CM334 line. In addition, our histological analyses of a $C$. аnnuum-resistant line provide relevant information about the spatial relationship between host and pathogen; the timing of nematode penetration, nematode infection, and host response; and how the resistance response varies with different Meloidogyne spp. We also showed that the response to different root-knot nematodes in susceptible and resistance plants was correlated (i.e., the more quickly a nematode species established feeding sites in the susceptible host, the more quickly it was recognized and immobilized in the resistant host).

\section{ACKNOWLEDGMENTS}

We thank M. Nicole for helpful discussions, J. de Almeida Engler for critically reading the manuscript, L. Pijarowski for helping in the bibliographic study, P. Lecomte for technical assistance in histological experiments, and M. Ponchet and L. Lapeyre for assistance in HPLC analysis.

\section{LITERATURE CITED}

1. Andary, C., Mondolot-Cosson, L., and Dai, G. H. 1996. In situ detection of polyphenols in plant-microorganism interactions. Pages 45-53 in: Histology, Ultrastructure and Molecular Cytology of Plant-Microorganism Interactions. M. Nicole and V. Gianinazzi-Pearson, eds. Kluwer Academic, Dordrecht, the Netherlands.
2. Anwar, S. A., and McKenry, M. V. 2000. Penetration, development and reproduction of Meloidogyne arenaria on two new resistant Vitis spp. Nematropica 30:9-17.

3. Anwar, S. A., Trudgill, D. L., and Philipps, M. S. 1994. The contribution of variation in invasion and development rates of Meloidogyne incognita to host status differences. Nematologica 40:579-586.

4. Bajaj, K. L., and Mahajan, R. 1977. Phenolic compounds in tomato susceptible and resistant to Meloidogyne incognita (Kofoid et White). Chitwood. Nematol. Mediterr. 5:329-333.

5. Baker, C. J., and Orlando, B. W. 1995. Active oxygen in plant pathogenesis. Annu. Rev. Phytopathol. 33:299-321.

6. Bingefors, S. 1982. Nature of inherited nematode resistance in plants Pages 187-219 in: Pathogens Vectors and Plant Diseases: Approaches to Control. K. F. Harris and K. Maramorosh, eds. Academic Press, New York.

7. Bird, A. F. 1961. The ultrastructure and histochemistry of a nematodeinduced giant cell. J. Cell. Biol. 11:701-715.

8. Bleve-Zaccheo, T., Bongiovanni, M., Melillo, M. T., and CastagnoneSereno, P. 1998. The pepper resistance genes $\mathrm{Mel}$ et $\mathrm{Me} 3$ induce differential penetration rates and temporal sequences of root cell ultrastructural changes upon nematode infection. Plant Sci. 133:79-90.

9. Brown, A. H. D., Garvin, D. F., Burdon, J. J., Abbott, D. C., and Read, B. J. 1996. The effect of combining scald resistance genes on disease levels, yield and quality traits in barley. Theor. Appl. Genet. 93:361-366.

10. Byrd, D. W., Kirkpatrick, T., and Barker, K. R. 1983. An improved technique for clearing and staining plant tissues for detection of nematodes. J. Nematol. 15:142-143

11. Caranta, C., Thabuis, A., and Palloix, A. 1999. Development of a CAPS marker for the Pvr4 locus: A tool for pyramiding potyvirus resistance genes in pepper. Genome 42:1111-1116.

12. Castagnone-Sereno, P., Bongiovanni, M., and Djian-Caporalino, C. 2001. New data on the specificity of the root-knot nematode resistance genes Mel and Me3 in pepper. Plant Breed. 120:429-433.

13. Castagnone-Sereno, P., Bongiovanni, M., Palloix, A., and Dalmasso, A. 1996. Selection for Meloidogyne incognita virulence against resistance genes from tomato and pepper and specificity of the virulence/resistance determinants. Eur. J. Plant Pathol. 102:585-590.

14. Clark, R. S., Kuc, J., Henze, R. E., and Quacenbush, F. W. 1959. The nature and fungitoxicity of an amino acid addition product of chlorogenic acid. Phytopathology 49:594-598.

15. Cotton, J., and Hayes, J. D. 1969. Genetic resistance to the cereal cyst nematode (Heterodera avenae). Heredity 24:596-601.

16. Dautova, M., and Gommers, F. J. 2000. Meloidogyne spp. in Macedonia: Distribution and virulence for $M i$ resistance in tomato. Nematol. Mediterr. 28:121-128.

17. Davis, E. L., Hussey, R. S., Baum, T. J., Bakker, J., Schots, A., Rosso, M. N., and Abad, P. 2000. Nematode parasitism genes. Annu. Rev. Phytopathol. 38:365-396.

18. Dixon, R. A., and Harisson, M. J. 1994. Early events in the activation of plant defence responses. Annu. Rev. Phytopathol. 32:479-501.

19. Djian-Caporalino, C., Pijarowski, L., Fazari, A., Samson, M., Gaveau, L., O’Byrne, C., Lefebvre, V., Caranta, C., Palloix, A., and Abad, P. 2001. High-resolution genetic mapping of the pepper (Capsicum annuum L.) resistance loci $\mathrm{Me}_{3}$ and $\mathrm{Me}_{4}$ conferring heat-stable resistance to root-knot nematodes (Meloidogyne spp.). Theor. Appl. Genet. 103:592-600.

20. Djian-Caporalino, C., Pijarowski, L., Januel, A., Lefebvre, V., Daubeze, A., Palloix, A., Dalmasso, A., and Abad, P. 1999. Spectrum of resistance to root-knot nematodes and inheritance of heat-stable resistance in pepper (Capsicum annuum L.). Theor. Appl. Genet. 99:496-502.

21. Dogimont, C., Palloix, A., Daubeze, A. M., Marchoux, G., GebreSelassie, K., and Pochard, E. 1996. Genetic analysis to broad spectrum resistance to potyviruses using doubled haploid lines of pepper (Capsicum annuиm). Euphytica 88:231-239.

22. Dropkin, V. H., and Nelson, P. E. 1960. The histopathology of root-knot nematode infections in soybeans. Phytopathology 50:442-447. 
23. Eddaoudi, M., Ammati, M., and Rammah, A. 1997. Identification of the resistance breaking populations of Meloidogyne on tomatoes in Morocco and their effect on new sources of resistance. Fundam. Appl. Nematol. 20:285-289.

24. Endo, B. Y. 1965. Histological responses of resistant and susceptible soybean varieties and backcross progeny to entry and development of Heterodera glycines. Phytopathology 53:375-381.

25. Endo, B. Y. 1991. Ultrastructure of initial response of susceptible and resistant soybean roots to infection by Heterodera glycines. Rev. Nematol. 14:73-94.

26. Fassuliotis, G., Deakin, J. R., and Hoffman, J. C., 1970. Root-knot nematode resistance in snap beans: Breeding and nature of resistance. J. Am. Soc. Hortic. Sci. 95:640-645.

27. Ferris, H. S., Schneider, S. M., and Stuth, M. C. 1982. Probability of penetration and infection by root-knot nematode Meloidogyne arenaria, in grape cultivars. Am. J. Enol. Viticult. 33:31-35.

28. Fery, R. L., and Thies, J. A. 1997. Evaluation of Capsicum chinense Jacq. cultigens for resistance to the southern root-knot nematode. Hortscience 32:923-926.

29. Giebel, J. 1970. Phenolic content in roots of some Solanaceae and its influence on IAA-oxidase activity as an indicator of resistance to Heterodera rostochiensis. Nematologica 16:22-32.

30. Grundler, F. M. W., Sobezak, M., and Lange, S. 1997. Defense responses of Arabidopsis thaliana during invasion and feeding site induction by the plant-parasitic nematode Heterodera glycines. Physiol. Mol. Plant Pathol. 50:419-429.

31. Hayne, R. L., and Jones, C. M. 1976. Effects of the Bi locus in cucumber on reproduction, attraction, and response of the plant to the southern rootknot nematode. J. Am. Soc. Hortic. Sci. 101:422-424.

32. Hendy, H., Dalmasso, A., and Cardin, M. C. 1985. Differences in resistant Capsicum annuum attacked by different Meloidogyne species. Nematologica 31:72-78.

33. Hendy, H., Pochard, E., and Dalmasso, A. 1983. Identification de 2 nouvelles sources de résistance aux nématodes à galles chez le piment. Note présentée par P. Pécaut. C.R. Acad. Agric. France 11:817-822.

34. Huang, C. L., and Rhode, R. A. 1973. Phenol accumulation related to resistance in tomato to infection by root-knot and lesion nematodes. J. Nematol. 5:253-258.

35. Hutcheson, S. W. 1998. Current concepts of active defense in plants. Annu. Rev. Phytopathol. 36:59-90.

36. Jarquin-Barberena, H., Dalmasso, A., de Guiran, G., and Cardin, M. 1991. Acquired virulence in the plant parasitic nematode Meloidogyne incognita. Rev. Nématol. 14:261-275.

37. Jaubert, S., Laffaire, J.-B., Abad, P., and Rosso, M. N. 2002. A polygalacturonase of animal origin isolated from the root-knot nematode Meloidogyne incognita. FEBS Lett. 522:109-112.

38. Kaloshian, I., Yaghoobi, J., Liharska, T., Hanson, D., Hontelez, J., Hogan, P., Jesse, T., Wijbrandi, J., Simons, G., Zabel, P., and Williamson, V. M. 1998. Genetic and physical localization of the root-knot nematode resistance locus Mi in tomato. Mol. Gen. Genet. 257:376-385.

39. Kaplan, D. T. 1978. Characterization of soybean incompatibility to Meloidogyne incognita and its association to glyceollin accumulation in infected root tissue. Ph.D. diss. University of California, Riverside.

40. Keen, N. T., and Bruegger, B. B. 1977. Phytoalexins and chemicals that elicit their production in plants. Pages 1-26 in: Host Plant Resistance to Pests. P. Hedin, ed. ACS Symp. Ser. Am. Chem. Soc. Ser. No. 62.

41. Keen, N. T., and Littlefield, L. H. 1979. The possible association of phytoalexins with resistance gene expression in flax to Melampsora lini. Physiol. Plant. Pathol. 14:265-280.

42. Khan, M. W., and Haider, S. H. 1991. Comparative damage potential and reproduction efficiency of Meloidogyne javanica and races of $M$. incognita on tomato and eggplant. Nematologica 37:293-303.

43. Milne, D. L., Boshoff, D. N., and Buchan, P. W. W. 1965. The nature of resistance of Nicotiana repanda to the root-knot nematode, Meloidogyne javanica. S. Afr. Agric. Sci. 8:557-567.

44. Nicholson, R. L., and Hammerschmidt, R. 1992. Phenolic compounds and their role in disease resistance. Annu. Rev. Phytopathol. 30:369-389.
45. Novacky, A., Pike, S. M., and Popham, P. L. 1993. Varying membrane properties of cells in tissues inoculated with HR-inducing bacteria. Pages 75-93 in: Biotechnology and Plant Protection, Bacterial Pathogenesis and Disease Resistance. D. Bills and S. D. Kung, eds. Butterworth, Guildford, UK.

46. Ornat, C., Verdejo-Lucas, S., and Sorribas, F. J. 2001. A population of Meloidogyne javanica in Spain virulent to the $M i$ resistance gene in tomato. Plant Dis. 85:271-276.

47. Palloix, A., Daubeze, A. M., Phaly, T., and Pochard, E. 1990. Breeding transgressive lines of pepper for resistance to Phytophthora capsici in a recurrent selection system. Euphytica 51:141-150.

48. Paulson, R. E., and Webster, J. M. 1972. Ultrastructure of the hypersensitive reaction in roots of tomato, Lycopersicon esculentum L., to infection by the root-knot nematode, Meloidogyne incognita. Physiol. Plant Pathol. 2:227-234.

49. Pi, C. L., and Rhode, R. A. 1967. Phenolic compounds and host reaction in tomato to injury caused by root knot and lesion nematodes. (Abstr.) Phytopathology 57:344.

50. Pontier, D., Gan, S. S., Amasino, R. M., Roby, D., and Larn, E. 1999. Markers for hypersensitive response and senescence show distinct patterns of expression. Plant Mol. Biol. 39:1243-1255.

51. Powell, N. T. 1962. Histological basis of resistance to root-knot nematodes in flue-cured tobacco. (Abstr.) Phytopathology 52:25.

52. Ribereau-Gayon, P. 1968. Les composes phénoliques des végétaux, Dunod, ed. Paris.

53. Rice, S. L., Leadbeater, B. S. C., and Stone, A. R. 1985. Changes in cell structure in roots of resistant potatoes parasitized by potato cystnematodes: Potatoes with resistance gene $H 1$ derived from Solanum tuberosum spp. andigena. Physiol. Plant Pathol. 27:219-234.

54. Rosso, M. N., Favery, B., Piotte, C., Arthaud, L., de Boer, J. M., Hussey, R. S., Bakker, J., Baum, T. J., and Abad, P. 1999. Isolation of a cDNA encoding a beta-1,4-endoglucanase in the root-knot nematode Meloidogyne incognita and expression analysis during plant parasitism. Mol. Plant-Microbe Interact. 12:585-91.

55. Sasser, J. N. 1977. Worldwide dissemination and importance of the rootknot nematode, Meloidogyne spp. J. Nematol. 22:585-589.

56. Semblat, J. P., Rosso, M. N., Hussey, R. S., Abad, P., and CastagnoneSereno, P. 2001. Molecular cloning of a cDNA encoding an amphidsecreted putative avirulence protein from the root-knot nematode Meloidogyne incognita. Mol. Plant-Microbe Interact. 14:72-79.

57. Sillero, J. C., and Rubiales, D. 2002. Histological characterization of resistance to Uromyces viciae-fabae in faba bean. Phytopathology 92:294-299.

58. Singh, S., Sidhu, J. S., Huang, N., Vikal, Y., Li, Z., Brar, D. S., Dhaliwal, H. S., and Khush, G. S. 2001. Pyramiding three bacterial blight resistance genes (Xa5, Xa13 and $\mathrm{Xa21}$ ) using marker-assisted selection into indica rice cultivar PR106. Theor. Appl. Genet. 102:1011-1015.

59. Tanda, A. S., Atwal, A. S., and Bajaj, Y. P. S. 1989. In vitro inhibition of root-knot nematode Meloidogyne incognita by Sesame root-exudate and its amino acids, Nematologica 35:115-124.

60. Tzortzakakis, E. A., and Gowen, S. R. 1996. Occurrence of a resistance breaking pathotype of Meloidogyne javanica on tomatoes in Crete, Greece. Fundam. Appl. Nematol. 19:238-288.

61. Valette, C., Andary, C., Geiger, J. P., Sarah, J. L., and Nicole, M. 1998. Histochemical and cytochemical investigations of phenols in roots of banana infected by the burrowing nematode Radopholus similis. Phytopathology 88:1141-1148.

62. Wyss, U., Grundler, F. M. W., and Munch, A. M. 1992. The parasitic behaviour of second-stage juveniles of Meloidogyne incognita in roots of Arabidopsis thaliana. Nematologica 38:98-111.

63. Ye, G., McNeil, D. L., and Hill, G. D. 2002. Breeding for resistance to lentil Ascochyta blight. Plant Breed. 121:185-191.

64. Yu, M. H., and Steele, A. E. 1981. Host-parasite interaction of resistant sugar beet and Heterodera schachtii. J. Nematol. 13:206-212.

65. Zijlstra, C., Donkers-Venne, T. H. M., and Fargette, M. 2000. Identification of Meloidogyne incognita, $M$. javanica and $M$. arenaria using sequence characterised amplified region (SCAR) based PCR assays. Nematology 2:847-853. 